Journal of English Language Teaching and Applied Linguistics

ISSN: 2707-756X

DOI: $10.32996 /$ jeltal

Journal Hompage: www.al-kindipublisher.com/index.php/jeltal

\title{
Communicative Sessions in Mixed-abilities Classroom: The Big Challenge for Low Achievers
}

Nedia Bellil

EFL Teacher/Phd.Student, University of Sfax, English department, Tunisia

Corresponding Author: Nedia Bellil, E-mail: nedia_bellil30@yahoo.fr

ARTICLE INFORMATION

Received: November 12, 2020

Accepted: December 14, 2020

Volume: 2

Issue: 5

DOI: 10.32996/jeltal.2020.2.5.7

\section{KEYWORDS}

low achievers, mixed-abilities classes, communicative sessions, low achievers' motivation

\section{ABSTRACT}

Theoretically speaking, the communicative approach, and the communicative sessions based on it may seem to be suitable to all teaching contexts. However, in real classroom context, realities may be different especially in mixed abilities classes. This study is an attempt to bring awareness of the different kinds of difficulties low achievers face during the communicative sessions in mixed abilities classrooms. It tries to build links between the principles on which those sessions are built and the difficulties engendered by mixed-abilities classes. Data were collected by means of a questionnaire and an interview for both students and teachers of English, in addition to an observation of a number of communicative sessions in the Tunisian ELT context. The study revealed that the majority of low-level students are unable to cope with those sessions. They are highly demanding for them especially in a mixed-abilities context. They negatively affect low achievers' self-esteem and motivation to learn English. The findings of the study can be used to enrich and support other researches dealing with similar issues. They can also help in deciding on the adequate solutions to low achievers' problems with communicative activities in mixed-abilities learning context.

\section{Introduction}

The study is conducted in a TEFL context. In Tunisia, English is taught as a foreign language at schools starting from the fifthgrade basic education until the fourth form secondary education, i.e. students study English as an obligatory school subject for nine years. In preparatory schools, apart from the lesson sessions, students have a communicative session per week. They do not learn lessons during it, they are only supposed to engage in communicative activities. It is also crucial to mention that English classes in the Tunisian EFL context are basically mixed-abilities where proficiency level differs significantly from one student to another.

The activities underlying the communicative sessions are supposed to be basically communicative and interactive. Typical activities adopted are role play, educational videos, interactive games, group/pair work, classroom discussion.... However, in line with my work as a teacher of English I have always noticed low-achievers' reluctance to take part in communicative activities. Their motivation to participate seemed too low. In addition, it seemed that they were taking no leaning benefits from those sessions. The dominance of high achievers was a characteristic feature of mixed-abilities classes. Accordingly, this study examined the phenomenon from different perspective. First, light was shed on the different aspects of the communicative approach on which communicative sessions were built. Then, those aspects were related to different motivation theories, added to low achievers learning difficulties in mixed-abilities classes.

This study rests upon the assumption that many of the fundamental principles of the Communicative Approach followed during the communicative sessions do not go along with the limited abilities of low proficiency-level students in the Tunisian ELT context. The Communicative activities underlying those sessions are highly demanding for low achievers, which

K C AL-KINDI CENTER $\mathbf{R}$ D FOR RESEARCH Your gatewoy to world-class resecrch
Published by Al-KindiCenter for Research and Development. Copyright (c) the author(s). This is an open access article under CC BY license (https://creativecommons.org/licenses/by/4.0/) 
negatively affects their motivation to learn English. In most cases, those sessions reinforce only high achievers learning results and boost their proficiency level.

\section{Literature Review}

In order to better understand the problem of low level students with the Communicative sessions, it is indispensible to scrutinize the important features of communicative classroom, mixed-abilities classes, and L2 motivation.

\subsection{Features of a communicative classroom}

\subsubsection{Communicative Approach}

Despite the fact that teachers today have the elasticity to move from one approach to another, still, those communicative sessions are basically founded on fundamental guidelines of the Communicative Approach. According to the seminal works of the advocators of the Communicative Approach, mainly Krashen and Terrel (1983), Halliday (1973), Berns (1984) and Hymes (1972), the following headings are the top ten principles of communicative language teaching:

- English must be taught in English. Translation is discouraged. Resort to students' mother tongue to explain new vocabulary or structure is not permitted. New words should be illustrated with pictures, situations, games...

- Lessons should be learner-centred. Students are encouraged to express their opinions and to initiate questions as active students' involvement guarantees better learning.

- Task-based lessons enhance effective language learning.

- Positive reinforcement helps learning, while over correction inhibits students. Errors are generally tolerated as priority is given to communication.

- Language skills are equally emphasized. They are integrated from the first stages of language learning.

- . Language should be taught as a live communicative medium. Connection between classroom activities and their transfer to real life situations is required.

- Students' motivation and positive attitude towards the learning context are essential for effective learning. Good teachers motivate students through materials and methods.

- Grammar and vocabulary are taught inductively in meaningful context.

- Language should be practised through activities which contextualize teaching. High reliance on audio-visual aids is indispensible to motivate students and facilitate teaching.

- Lessons are no longer teacher centred. They should be learner-centred. The teacher just guides, assists, and facilitates learning.

\subsubsection{The role of the teacher}

In defining the teacher's role in communicative classrooms, Larsen-Freeman (1986) argues that teachers are becoming active facilitators of their students' learning in the communicative classroom where they find themselves listening more and talking less. Because students' performance is the goal, the teacher sets up the exercise, then steps back and observes. The students do most of the speaking, and frequently the scene of a classroom during a communicative task is active with students leaving seats to complete a task. Because of the increased responsibility to participate, students may find themselves gaining confidence in using the target language. In general, students are more responsible managers of their own learning (LarsenFreeman, 1986).

In this respect, Littlewood (1981, p.92) says: "The concept of the teacher as an instructor is thus inadequate to describe his overall function". He summarises the role of the teacher in communicative language learning in four sub roles. According to him, the teacher should essentially be the coordinator, the adviser, monitors and the co-communicator with the learners. Thus, changes in the teacher's role mean tremendous changes in the pupil's role in communicative classes.

Alongside the same lines Richards (2006) points out that "teachers now had to assume the role of facilitator and monitor. Rather than being a model for correct speech and writing and one with the primary responsibility of making students produce plenty of error-free sentences". (p. 5) 


\subsubsection{The role of student}

In the Communicative Approach, students are given the chance to initiate questions, suggest activities and express opinions. "It is the learners themselves who become the major teaching resource. There is a sense in which the teacher becomes a learner and learners are transferred into teachers" (Campbell \& Kryszewska, 1992, p.3). Students are supposed to use language, which has been imperfectly mastered, to negotiate meaning. Thus, the learner shaped by the Communicative Approach is a conscious one, aware of the teaching act, and mature enough to make suitable decisions to better acquire the language. In a similar vein, Richards (2006) says that students within a communicative language learning approach "had to become comfortable with listening to their peers in group work or pair work tasks, rather than relying on the teacher for a model. They were expected to take on a greater degree of responsibility for their own learning" (p. 5). However, this view of learners can be, to an important extent, paradoxical regarding the limited abilities of low proficiency-level students who may be unable to assume the responsibility of these roles and are still in need of their teacher guidance in the different stages of the lesson.

\subsubsection{Classroom atmosphere}

Classroom atmosphere in a communicative class is basically characterised by communication. It is far from being quiet. Students have to do most of the speaking. Because of the increased responsibility to participate intensively, students may find themselves gaining confidence in using the target language. In general, students are more responsible managers of their own learning (Larsen-Freeman, 1986). In addition, classroom atmosphere should be tailored to the needs and preferences of students in order to motivate them and create in them positive attitudes towards language learning. Littlewood (1981) maintains that communicative activities provide opportunities to develop positive personal relationships between learners and teachers and among learners themselves. He further adds that these relationships help to "humanise" the classroom and create a supportive environment to the learner in his efforts to acquire the language. More recently, Denkci-Akkas and Coker (2016) assert that "The communicative approach aims to give learners more control and autonomy of their own learning via student-centred group work activities and the chance to control the content of the classroom instruction". (p.82)

\subsection{Mixed-abilities classes}

English classrooms in the Tunisian context are basically mixed-abilities. They are composed of students whose proficiency level ranges from low to high. Rinvolucri (1994) states that: "we have to recognize that we are teaching a group of individuals not a single student with 25 faces". Indeed, language practitioners should not expect students to be the same. This is because every class is made up of a group of individuals who are different in terms of their knowledge and abilities. To be more specific, 'mixed-abilities' refers to:

- Classes in which there are very clear differences in learning language level among the students.

- Classes where learning styles, speed, attitudes and motivation level among the students largely differ from one student to another.

- Classes where there are clear differences in the students' background knowledge and their talents and skills in other areas. (Rinvolucri,1994)

In the same context, Bremner (2008) maintains that mixed-ability classes are not just composed of students with different learning abilities, but also students with a variety of learning preferences, styles. Therefore, students differ in their achievement, motivation, participation and their endeavour to learn the foreign language. Additionally, Syathroh et al. (2019) maintain that the existence of mixed-ability classes in the daily practice of education is often unavoidable. They are usually composed of students with having different characteristics, in terms of their, proficiency, educational backgrounds, motivations, learning styles, etc. Elizondo (2013) calls mixed abilities class "the mixed-proficiency language class" (MPLC). she defines it as "the situation faced when students with different language proficiency levels (beginner, intermediate, and advanced) are placed in the same group to receive language instruction" (p. 112). In this type of learning situations, some students are beginners with very limited ability to communicate while others are advanced learners able to handle almost any communicative situation they are given in class.

In fact, the existence of mixed-abilities classes in Tunisia can be ascribed to many factors: Students come from different learning backgrounds. Some may have had private lessons. Thus, they may have spent different amounts of time learning. They may also have had teachers who emphasized different skills or language areas. Furthermore, students' progress at different rates. This is due to different learning styles, cognitive abilities and the way students respond to the teacher's style 
and approach. Moreover, some students find learning a second language easy and others find it difficult, which means that learning aptitude differs from one learner to another.

\subsection{Low proficiency-level students}

"By definition, children who are low achievers are just students who are slower to make academic achievement. They are the students who likely have a great amount of difficulty in meeting educational standards". (Vanauker-Ergle, 2003, p.4). She further adds that low achievers have been described primarily as pupils who do not perform well in the classroom; they generally have low average and struggle to keep up with general academic requirements.

Alongside the same lines, low proficiency-level students in Tunisia are students who face different kinds of problems in keeping in pace with high achievers. After a fourteen-year experience of teaching, I have noticed that in every class there is a number of high achievers with whom the teacher can interact easily, whereas, the rest are low achievers who make, in most cases, teaching really challenging. Thus, dealing with high and low achievers at the same time, in the same class and in the same way is really a big challenge for the teacher.

\subsection{Motivation}

Motivation is one of the main determiners of human behaviour as it energises it, prompts it and gives it direction. In an attempt to synthesize the varied conceptions of motivation, Dörnyei (1998) defines it as " a process whereby a certain amount of instigation force arises, initiates action and persists as long as no other force comes into play to weaken it and thereby terminates action, or until the planned outcome has been reached". Saville-Troike (2006) sees L2 motivation as a construct including at least the following components:

- Significant goal or need.

- Desire to attend a goal.

- Perception that learning L2 is relevant for fulfilling the goal.

- Belief in the likely success or failure of L2 learning.

- Value of potential outcome/rewards.

In general, as Dörnyei (1996a) points out, motivation theories seek to answer the fundamental question of why humans behave the way they do. Accordingly, scrutinizing the issue of low achievers' motivation to learn English needs concentration on different motivation theories in mainstream psychological research, in addition to motivation in second and foreign language learning.

\subsubsection{Expectancy-Value Theories}

Expectancy-value theories rest upon the assumption that motivation to perform a given task is basically the product of two key elements: The expectancy of success in the task and the value attached to success in it. According to this theory, people who expect success and perceive it attainable will be highly motivated to accomplish a given task. Conversely, those who are convinced that achieving success is not possible for them, no matter how hard they try, will not be motivated and are unlikely to invest any effort. (Pintrich and Schunk, 1996).

\subsubsection{Attribution theory}

The main assumption of attribution theory is that individuals' achievement behaviour is considerably influenced by the way they process their past experiences of success and failure.

Dörnyei (2003) describes attributions theory as "unique" because, according to him, it manages to link people's past experiences with their future achievement efforts. Thus, positive judgement of one's prior failure by ascribing it to factors far from his own abilities such as luck, fatigue or task difficulty, can have its positive impact on his/her motivation to undertake the same task in the future. Conversely, the negative analysis of failure by ascribing it to one's low ability will undoubtedly impede motivation and discourage individuals to deal with the task again in order to avoid failure. 


\subsubsection{Self-efficacy theory}

Self-efficacy theory refers to the individuals' judgements and beliefs in their own capabilities to undertake and accomplish a given task and reach a given level of performance. Accordingly, the amount of effort that individuals may exert, the genre of activity they choose to carry out as well as their level of aspiration are determined by their sense of efficacy. Bandura (1993) maintains that people who have low level of self efficacy perceive difficult tasks as personal threats. Therefore, they easily lose faith in their capacities and tend to give up after the first obstacles they may encounter. Conversely, a huge sense of selfefficacy enhances peoples' achievement behaviour by helping them to approach challenging tasks with confidence, to maintain a task involvement, and to sustain efforts in the face of difficulties and failure.

\subsubsection{Self-worth theory}

Self-worth theory stems from the belief that humans tend to behave in a way that can enhance their positive self identity in order to get others' approval and stay distant from acts that may lead to social rejection. Hermassi (2003) states that self worth refers to the establishment and maintenance of a self image which is identical to internal standards and values. According to Convington (1984), the most important factor in shaping attitudes and behaviour is the individuals' sense of self worth, which emanates from perceptions of ability, especially in comparison to others. He further adds that setting reachable goals with a kind of tolerance for failure by finding can promote self worth. Therefore, students who believe that they are incompetent, develop a sense of helplessness and demoralisation, which may lead them to give up at the early stages of task achievement.

\subsection{Value}

Eccles and Wigfield (1995) maintain that the concept of value, in expectancy value theory, refers to the valuation of the undertaken action. People who give importance to a given task and view it as valuable are more likely to exert considerable effort with a feeling of pleasure which accompanies the accomplishment of the task. In contrast, individuals who devalue success and perceive it as useless tend to keep away from achievement situations.

\subsection{Goal-setting theory}

Locke and Latham (1994) assert that human action is caused by purpose, and for action to take place, goal should be set and pursued willingly. In goal-setting theory psychologists put much emphasis on goal characteristics as key factors that enhance motivation and make individuals committed to task accomplishment and goal achievement. Clear, specific, and reachable goals are believed to be instigators of achievement-oriented behaviour. Whereas, once the goal is judged as vague and unattainable, individuals are more likely to relinquish in front of obstacles they may encounter. In this vein, Locke and Krisof (1996) maintain, relying on the analysis of over 400 studies, that goals that are specific and difficult lead to high performance more than goals which are vague or goals that are specific but easy.

\subsubsection{Goal-orientation theory}

The main two constructs underlying the theory are mastery orientation and performance orientation. Students who adopt a mastery orientation pursue learning goals with the focus on the content. The belief that effort leads to success is central to learning goal. However, students who follow a performance orientation pursue performance goals focusing on getting good marks, outdoing others, or demonstrating abilities. Learning here is considered as a way to reach a goal and get the accompanying recognition. Ames (1992) believes in the superiority of mastery goal on performance goal arguing that mastery goals are associated with a tendency for challenging difficulties, an intrinsic interest in learning activities, and a positive attitude towards the learning task.

\subsubsection{Self-determination theory}

Deci and Ryan's (1985) self-determination theory is based on the distinction between intrinsic and extrinsic motivation. Noels et al. (2000, p.60) state: "According to self-determination theory, there are two general types of motivation; one based on intrinsic interest in the activity per se and the other based on rewards extrinsic to the activity itself ". Intrinsic motivation refers to motivation to perform a given task for its own sake. This type of motivation is generally instigated by the desire to accomplish a task and experience the feeling of satisfaction accompanied by task completion, especially challenging ones. In contrast, individuals who are extrinsically motivated approach a task as a means to an end, i.e., to achieve instrumental ends like rewards, good grades, words of recognition, or to avoid punishment. 


\subsection{Motivation in second and foreign language learning}

Motivation to learn a second language has been the main concern of motivational psychologists and educationalists for decades (Gardner 1985a, 1998a, 2001; Gardner and Lambert 1972, Ellis 1994, Dörnyei 1994a, 1994b, 1998, 2003) regarding the crucial role it plays in L2 learning and achievement. Gardner's seminal work on motivation to learn a second/foreign language dominated L2 motivation research during the 1980s until the beginning of the 1990s, which witnessed a revival in interest in L2 motivation.

\subsection{Gardner's Social psychological Approach}

Gardner (1985, p.10) defines L2 motivation as the "the extent to which an individual works or strives to learn the language because of a desire to do so and the satisfaction experienced in the activity". Motivational intensity, desire to learn the language, and the attitude towards the act of learning are the three components of Gardner's motivation theory. Central to Gardner's theory of L2 motivation is the dichotomy between integrative motivation and instrumental motivation.

\subsubsection{Integrative motivation}

Integrative motivation is motivation to learn a second/foreign language which is fuelled by positive attitude toward the speech community of that language and the desire to identify with them. Johnson (2001, p.131) states: "We say that someone is integratively motivated if they are learning the foreign language through the desire to learn more about the culture, its language and people to integrate more within the target language society."

\subsubsection{Instrumental motivation}

Instrumental motivation, on the other hand, refers to motivation to learn a language in order to achieve utilitarian purposes such as passing an exam or meeting educational requirements. In other words, language learning is approached as a means to an end. Johnson's (2001, p.133) says that instrumental motivation involves" learning to achieve some goals". Gardner (2001) argues that persons who are instrumentally motivated are seeking “... a goal that doesn't seem to involve any identification or feeling of closeness with other language group, but instead focus on a more practical purpose that language learning would serve for the individual".

\section{Methodology}

\subsection{Research setting and participants}

The data collection of this study was carried out in different secondary and preparatory school in various regions in Tunisia. Subjects in this study were 156 students and 28 teachers of English. What students had in common was their low proficiencylevel which was measured in the light of their marks at English. The majority of teachers taught in different levels. Their classes were all mixed-ability classes which included a significant number of low proficiency-level students.

\subsection{Research instruments}

This study adopts a mixed research method. It involves the combination of qualitative and quantitative research at the level of data collection as well as at the analysis level. Mixing methods can bring out the best of both paradigms. Dornyei (2007) states that the strengths of one method can be utilized to overcome the weaknesses of the other, which offers a potentially more comprehensive means of legitimizing the outcomes. In other words, mixing methods helps verify one set of findings against the other. Therefore, data in this research was collected by means of a questionnaire and an interview for students, in addition to a questionnaire and interview for teachers. They were all formulated in a way which helped to get the information needed in order to answer the research questions and support its main claims.

The fifth instrument of dada collection adopted in this study was classroom observation, as observation in central to all forms of evaluation. Lier (1998) argues in this context that whatever the methodology of research involved; classroom observation is a fundamental aspect of classroom research. Sixteen communicative sessions in different regions in Tunisia were observed on the purpose of gaining as rich data about the issue as possible. Teacher's feedback, low achievers' participation, pair and group work, classroom atmosphere, and communicative activities were the main aspects targeted by classroom observations.

\section{Results and Discussion}

The findings of the research were analysed under the following headings which are the main points targeted by the study: Teaching English in English, students' motivation, integration of skills, Pair/ group work, teachers' feedback, error correction, communicative sessions and communicative tasks. 


\subsection{Teaching English in English}

In fact, five questions in students' and teachers' questionnaire targeted the principle of teaching English in English. Answers to these questions showed that $100 \%$ of low achievers thought that it was difficult for them to perform in English during the English session. The following figure presents students' answers:

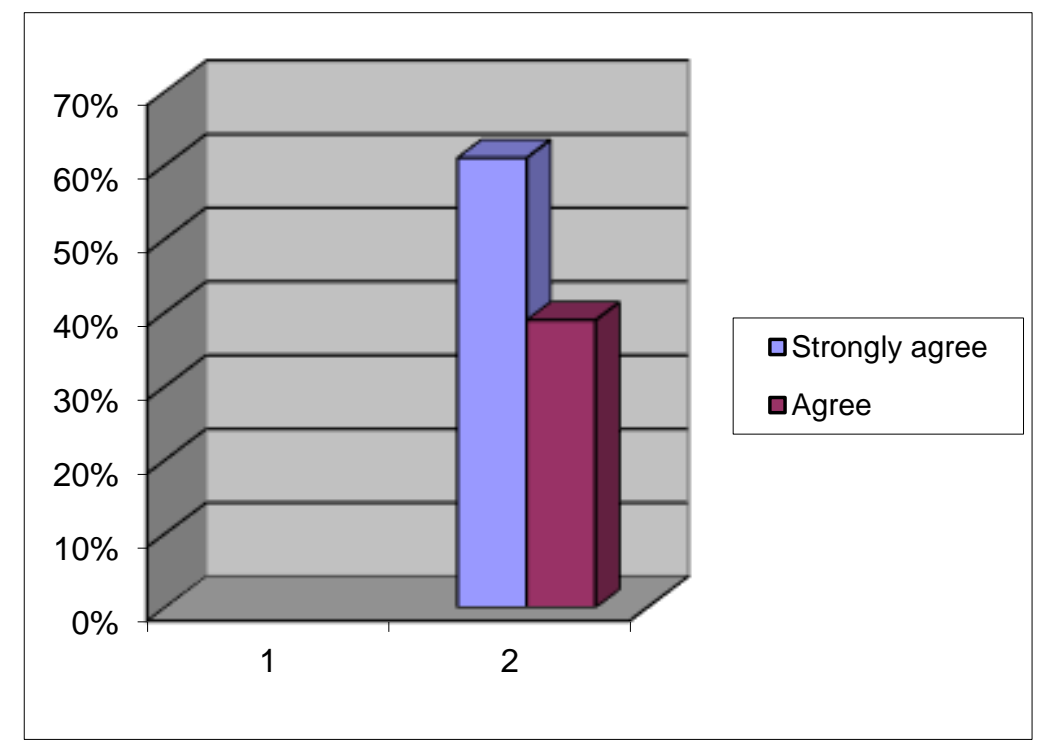

\section{figure 1: Difficulty to perform in English during the English session (According to students)}

All students said that the fact that their teacher speaks only English made the learning task more difficult for them. Moving to teachers, their answers came to confirm students' points of view. Teachers were asked whether they thought or felt that the overwhelming majority of the students understood them when they use English as the sole language of teaching with no shift to Arabic. Their answers were the following:

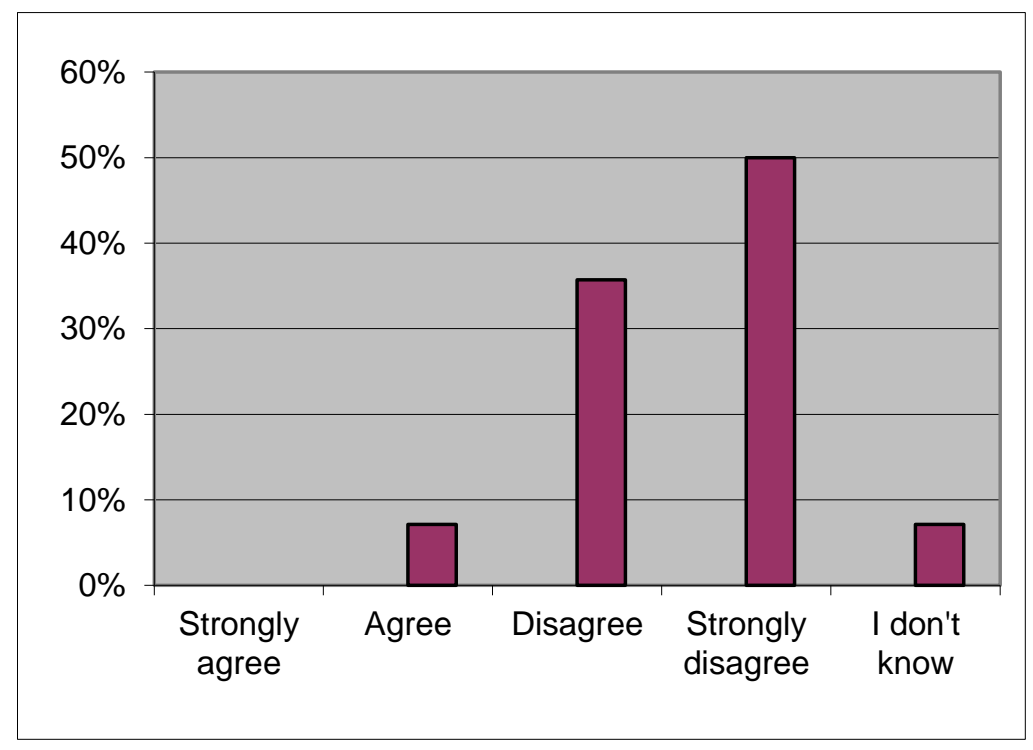

Figure 2: Students understanding of English (According to teachers)

After students, teachers were also asked about the need to shift to Arabic, as students' mother language, in order to solve many of the understanding problems during the teaching/learning process and make students' task clear enough. Although the percentage of teachers who agreed on this point was not as high as students' percentage, their responses came to back students' responses. Teachers admitted the fact that they often need to resort to Arabic to make their students' tasks clearer. 
However, the majority of them believe that English should be taught in English. Going back to the review of literature section, teachers' attitudes were similar Littlewood's (2001) opinion which says that the use of learners' mother tongue means sacrificing valuable opportunities for foreign language use.

Thus, one among the major principles of the Communicative Approach which is reliance only on English to teach English is a problem for students and teachers at the same time. Students think that it is difficult for them to perform in English and believe that the fact that their teacher speaks only in English makes the learning task more difficult for them. This may intensify the feeling of incapacity in them which affects negatively their motivation.

\subsection{Students' motivation}

As previously mentioned, motivation to learn a language is a key factor to achieve success in language acquisition. It is also, as Savielle-Troike (2006) argues, among the major factors which explain why some learners are more successful than others. Low achievers' motivation was revealed through their answers to the questionnaire and the interview. Students' opinions about the English language in general could be a significant indicator of their motivation to learn it. The overwhelming majority of them assumed that the English wasnot easy at all to learn. They consider English difficult and beyond their proficiency level. As mentioned in the review of literature section, this attitude can hinder their motivation as one among main instigators of motivation is 'a positive attitude towards the act of learning'. In addition, as seen in goal theories, there is a consensus between scholars, like Locke and Lathman (1990), Locke and Krisof (1996), Dornyei and Otto (1998); Pintrich and Schunk (1996), that considering the goal, which is the English language acquisition here, as attainable is indispensable to create motivation and instigate students' achievement-oriented behaviour, which was not the case with low achievers in the Tunisian SLA context. Therefore, by considering English difficult and the goal of acquiring it as unreachable, low achievers are unlikely to expect success. Thus, their motivation is negatively affected. In this study, students were asked whether they consider English acquisition beyond their proficiency level or not. Their answers are the following:

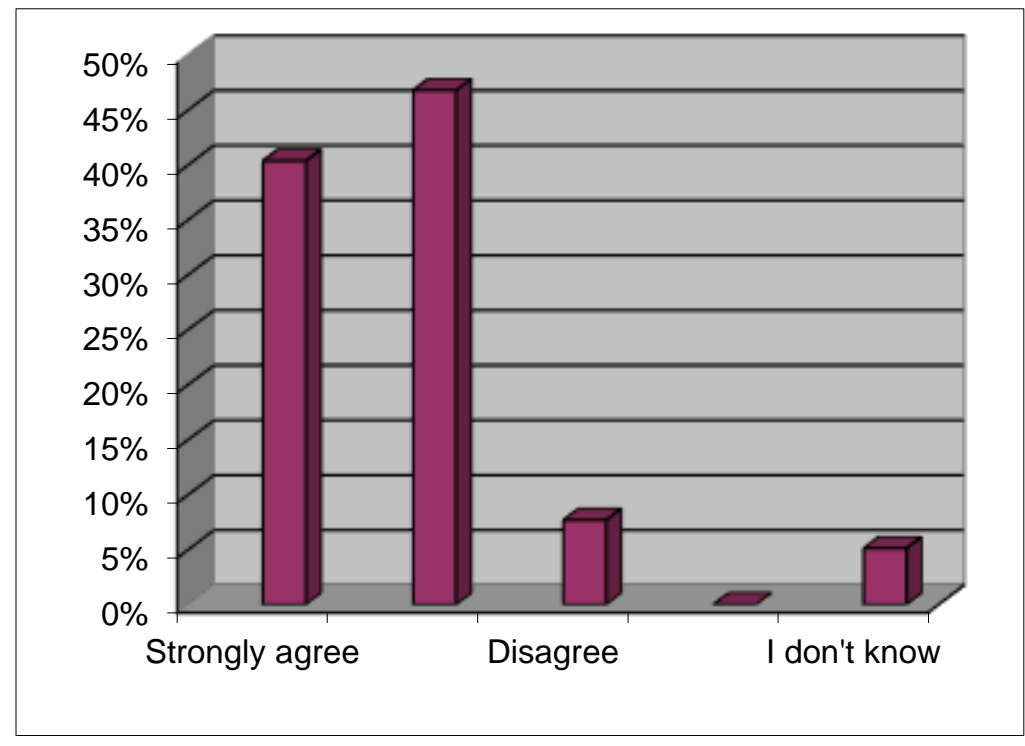

Figure 3: Students' opinions about the difficulty of acquiring the English language

It is clear then that students' self-esteem was too low as the overwhelming majority of students thought that English acquisition surpasses their proficiency level. This is because a high level of self-esteem basically means belief in one's capabilities to accomplish a task or to reach a goal, which is indispensable to instigate and sustain motivation. Low achievers had no strong beliefs in their own capabilities and judged English acquisition as being beyond their proficiency level. Hence, they were more likely to approach the task of learning English as threats to be avoided rather than challenges to be mastered.

As previously seen, Linguists and second language acquisition theorists insist on positive self-image as a key factor to success in language acquisition. According to them, no cognitive activity can be successfully carried without some degree of selfesteem, self-confidence, and beliefs in one's own capabilities. 


\subsection{Integration of skills}

In this study, integration of skills, as one of the principles of the Communicative Approach, was considered problematic for low achievers. Starting from an early stage of language learning, students are supposed to listen, speak, read and write in the same session. Thus, teachers were asked whether they thought that it was easy or difficult for low achievers to use the skills integrally. In fact, teachers had different opinions though almost all of them agreed that it is difficult for low achievers to learn the four skills in one session. Some of their opinions are the following:

- "Integrating the four skills is difficult especially during the early stages of English learning".

- "Every skill needs a number of sub skills. It is challenging for low achievers".

- "Low achievers are suffering mainly from listening and writing, thus, integrating them with the other two skills makes the tasks more difficult for low achievers".

- "Integrating the four skills is a problem for students because the other principles of the approach are themselves problematic and this, in fact, what makes the problems deeper".

Though teachers' opinions were different, they all admitted the fact that integrating the four skills together was, in one way or in another, problematic for low achievers. This indeed confirms one of the claims of this study which considers skills integration challenging for low proficiency level students.

\subsection{Pair and group work}

Despite the advantages of pair work and group work, there seemed to be some problems especially with low proficiencylevel students. When asked about working with classmates, $66.02 \%$ of students said that while working in pair or in group, they generally rely on high achievers to accomplish the assigned task as they believe that they are able to do better than them. $14.74 \%$ of them said that high achievers do not even give them the opportunity to participate. Only $11.53 \%$ of the students said that they really participate with their classmates to do the task.

Again, the problem here is not in group work and pair work as techniques of teaching and ways to achieve lessons' objectives, but in adopting them in mixed ability classes where the differences in proficiency level among students is huge.

\subsection{Classroom participation}

Classroom participation was taken into consideration in this study as it is a crucial indicator of students' motivation. It also reflects the success of the teaching/learning act. Teachers were asked whether low proficiency-level students participate frequently during the English class or not. Teachers' responses are presented in the following figure:

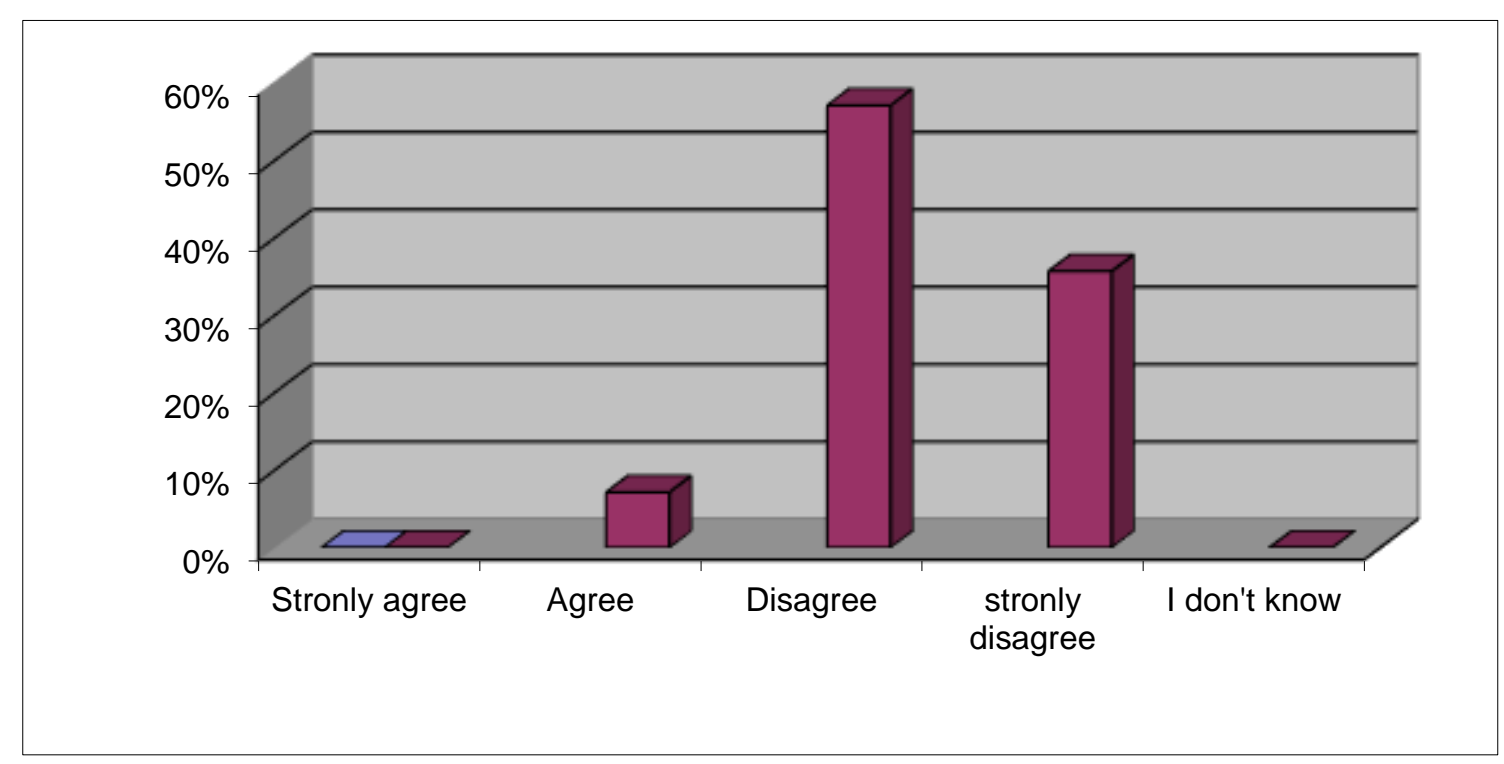

Figure 4: The intensity of classroom participation according to teachers 
Thus, the graph shows that $92,85 \%$ of answers ranges between disagree and strongly disagree, which means that low achievers do not participate frequently during the English session. Thus, students' low intensity of participation might be an indicator of their demotivation towards the English session. It might also mean that low achievers did not understand the lesson or the instructions which discouraged them to take risk and participate.

\subsection{Teacher's feedback}

Teacher's feedback, which is an indispensible constituent of classroom interaction, is one among the key factors to the success of the lesson as it is a kind of positive or negative reinforcement to students. Students were asked whether they sometimes feel that their teacher pays more attention to high proficiency-level students or not. Their answers are presented in the following graph:

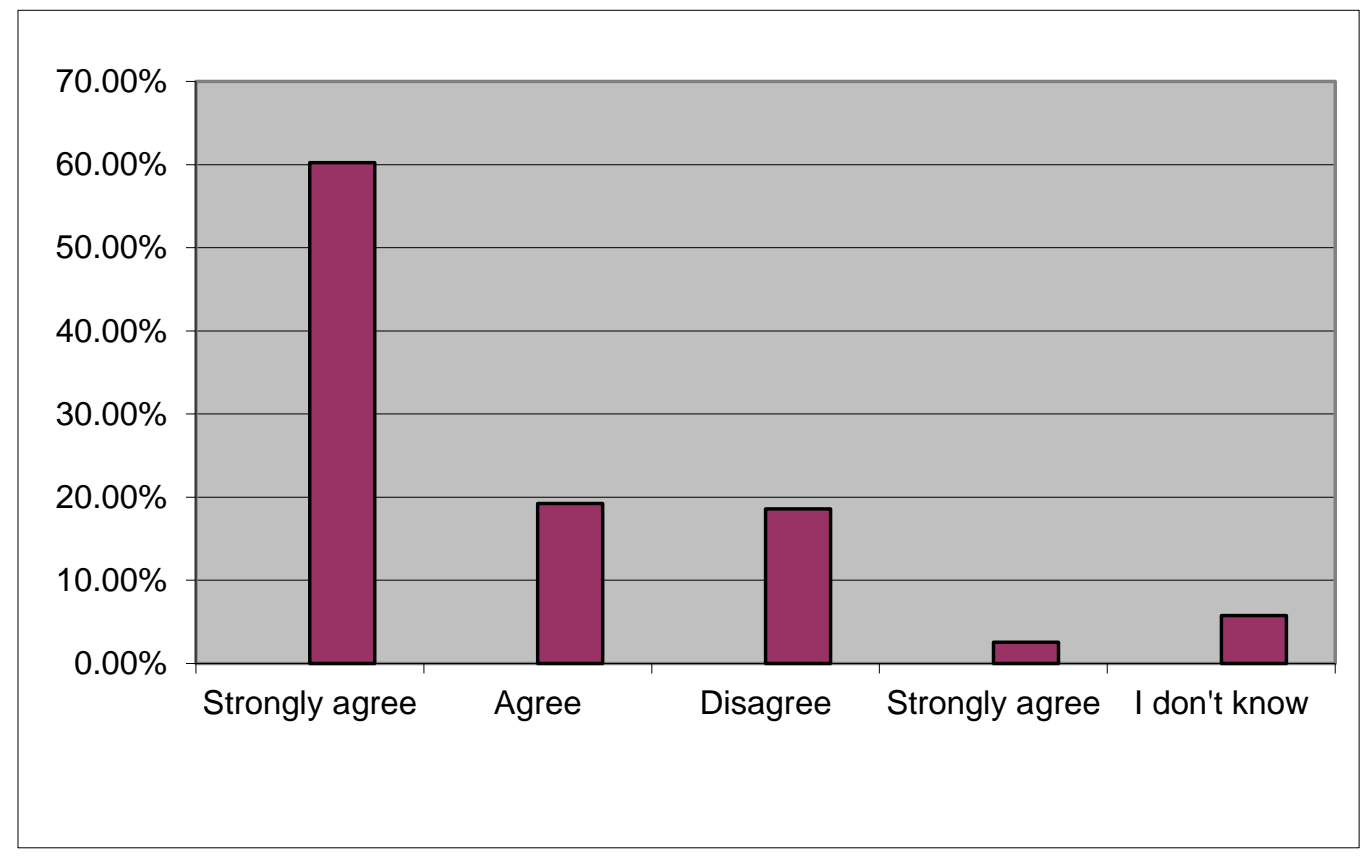

\section{Figure 5: The teacher's attention to high achievers during the English session (According to students)}

The figure shows that $79,48 \%$ of low proficiency-level students thought that their teachers paid more attention to high achievers during the English session. In explaining their points of view, a significant number of students said that high achievers usually have correct answers. In addition, they respond quickly to teacher's questions and instructions, which makes the interaction between them end with appreciation and recognition words.

Taking into consideration low achievers' self-esteem and motivation, this kind of interaction between the teacher and high achievers could have its negative impact on low proficiency-level students as it increases the feeling of incapability and inferiority in them. It might also make them consider that the goal of acquiring the English language as unattainable, which negatively affects their motivation. Undoubtedly, this doesn't mean that the problem is the good and positive kind of interaction between the teacher and good achievers, which is needed in any learning/teaching context, but with low achievers who could not keep in pace with that kind of interaction regarding their low proficiency-level.

\subsection{Error correction}

One among the ultimate goals of second language learning, according to the Communicative Approach, is the attainment of communicative fluency. In other words, priority is given to fluency at the expense of accuracy, which means a significant sense of tolerance with learners' errors. However, many teachers of English might not be convinced to do so and let learners' numerous and varied errors go without correction. Actually, this can lead to other kinds of problems. Nonetheless, overcorrection may inhibit students and hinder their competence development. Students were asked whether they considered their answers correct once they were not corrected by the teacher. Their answers are presented in the following figure: 


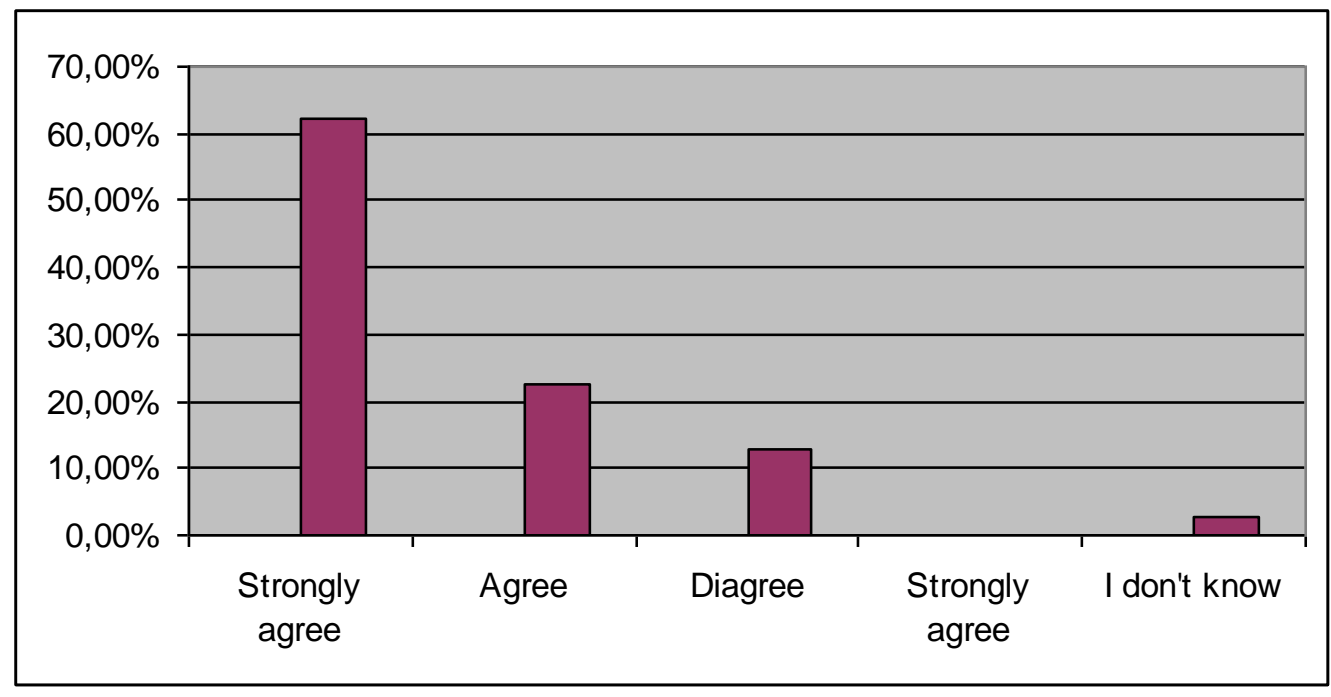

\section{Figure 6: Students who consider the uncorrected answers correct}

As the answers show, the overwhelming majority of students considered correct every answer which goes without correction. This is in fact logical as students do not know about the aim behind ignoring their errors. They come to the class with the beliefs that the teacher is their instructor and the sole holder of knowledge who is supposed to correct them whenever they make errors. This in fact hampers the process of language acquisition, as it may lead to many problems such as fossilisation and students' misinterpretation of their teacher's feedback. In this vein, Cathcart and Osten (1976) also concluded, after a study they conducted on 149 ESL learners, that students in the classroom want and expect their errors to be corrected; they showed a strong preference for correction of all errors.

As for teachers, they gave various opinions about this matter, but what they had in common is their belief that of error correction is problematic especially when dealing with low achievers. Some of their opinions are the following:

- "overcorrection can inhibit low achievers but the problem is that they are not aware of the reasons behind their teacher's ignorance of their errors".

- $\quad$ "yes, it is misleading because if I decide to correct some mistakes and neglect others for a given purpose, students won't know about that".

- "correcting some errors may lead learners to assume that the rest of their answer is correct".

- "dealing with low achievers' answers is really problematic for me. I usually neglect a great deal of their errors, as the Communicative Approach calls for, but deep in my mind I am convinced that this won't help low achievers".

Though it is convincing at the theoretical level that learners' errors should not be overcorrected to avoid inhibition and frustration, this really depends on the context of language learning and the proficiency level of students. The principle of tolerance with errors may not generate problems with high achievers as they do not make so many errors and they can understand easily the teacher's attempt to correct them. However, the matter is much more complicated with low achievers and may lead to many problems as seen in this section. Thus, again evidence shows that purely communicative sessions are not suitable to all students in all learning contexts.

\subsection{Communicative tasks and communicative sessions}

Participant teachers were asked whether they think that communicative tasks, which are the backbone of the communicative sessions, foster or hamper low proficiency-level students' motivation. Various points of view were gathered. Many teachers said that low achievers usually find problems in dealing with tasks assigned and consider them beyond their proficiency level. Others said that low achievers like communicative tasks, however, they do not actually participate in them because their communicative abilities are too limited. In most cases, they just sit back and keep watching their classmates performing these tasks. Other teachers said that low proficiency-level students generally misunderstand the main objectives of communicative tasks and consider them as occasions to have fun despite teachers' efforts to put them in the right direction. The rest of 
teachers said that they usually find problems in engaging low achievers with high achievers in communicative tasks regarding the huge differences in proficiency level which make low achievers in most cases unmotivated to carry on.

To conclude, though it is important for learners to have positive attitudes towards communicative sessions, however, their reasons behind preferring those sessions were shown to be totally far from the objectives designed for those sessions. The majority of students considered them sessions for just playing and having fun. Answers showed that students were not aware of the importance of the communicative tasks and communicative sessions.

the communicative sessions, and whether they are purely communicative or not. They were also asked about the reasons. Teachers gave different answers and reasons. Some of them are the following:

- "doing purely communicative tasks depends on the proficiency level of the students I am teaching because communicative tasks usually need high proficiency level and many students cannot be engaged in those tasks."

- "there is nothing, according to me, called purely communicative because I always intervene to make communicative tasks accessible to many students and my intervention may not keep them purely communicative".

- "I sometimes do purely communicative tasks in those sessions but, from time to time, I tend do consolidation activities at the level of grammar and vocabulary in order to improve students' proficiency level".

- "I $\mathrm{m}$ teaching in pioneers school, my students' proficiency level is too high. Yes, I spend those sessions doing purely communicative tasks without facing any problem without facing any problem with my students".

- " "to be honest, I rarely do purely communicative tasks in those sessions. The proficiency level of my students is too low. I prefer to consolidate their grammar and vocabulary before moving to communication".

- $\quad$ "yes, I spend those sessions doing purely communicative tasks, but I am sure that only high achievers take benefits of them".

The majority of teachers' answers showed that they think that communicative sessions were not very useful in improving low achievers' communicative competence because their knowledge of grammar, structure and vocabulary was too limited. In addition, low achievers, in general, have very low self-esteem and do not want to be engaged in communicative tasks which impede the development of their communicative competence. The majority of teachers considered those tasks more beneficial for high achievers

\subsection{Classroom Observation}

The fifth instrument of data collection in this study is classroom observation. Focus during observation was on classroom participation, teacher's feedback, the use of English as the sole language in the classroom, group work, and communicative activities. Regarding classroom participation, it was not so intensive. Almost the same few students were participating. Their answers were, in most cases, correct, and their pronunciation was, in general, good. However, the rest of students were reluctant to take part, except when the teacher assigns one of them to answer. Some of the assigned students gave wrong answers; the others did not give answers at all. They usually say, in Arabic, that they did not understand the question or the teacher's instructions. It is also worth noting here that these students were making so much noise, which may reflect their carelessness with the lesson.

Moving to teacher's feedback, it was characterised by words of appreciation and encouragement to high achievers. Interaction between the teacher and low achievers was almost rare. Interaction was generally between high and mediumlevel students, whereas, the rest were just observing. Error correction, as a part of teacher's feedback, was done in a direct and in an indirect way.

Regarding the use of English as the sole language to teach the English language, it is worth noting that the teacher used some Arabic words to better explain their instructions. Students also did not hesitate to speak in Arabic to ask for clarifications or for the meaning of some words.

In the communicative session, students with different proficiency levels were so motivated to engage in communicative tasks. In one of the observed sessions, students were preparing a role play (having lunch with a pen-friend). They were so noisy. The teacher gave them the freedom to divide themselves in groups, however, this was problematic. What was noticed is high achievers' tendency to work together, excluding their classmates because of their inability to deal with the assigned task and perform it in a good way. During the other sessions, it was the teacher who divided the class into groups. The same problem appeared, but in a different way. From time to time, one of the students tells the teacher that his/her classmates refuse to let him work with them, or, on the contrary, students in one group tell the teacher that their classmates were not 
cooperating with them. This, in fact, shows that students with different levels of proficiency were facing problems in working together.

After the teachers' and students' interview and questionnaire, classroom observation came to confirm the existence of different kinds of problems facing low achievers during communicative sessions in mixed-abilities classes. In fact, what was generally noticed during classroom observation was not so from the main results obtained through the two questionnaires and interviews.

\section{Conclusion}

The study investigated the fundamental principles of the Communicative Approach that low achievers cannot cope with during communicative sessions and in mixed abilities classes. Teaching English in English, high reliance on communication starting from the early stages of language learning, the communicative tasks, error treatment and correction, pair and group work, in addition to teacher's feedback were shown to be the origin of weak students' problems during the learning act. This study has also questioned the impact of the different principles of the Communicative Approach on low proficiency-level students' motivation, which is considered by the approach as key factor to success in second and foreign language acquisition. Concerning motivation, the research has shown that low achievers' attitude towards the English language, the act of learning, and the learning context were basically the reasons behind their low level of motivation to learn English.

The present study has also investigated the usefulness of group work and pair work to achieve success in language learning especially for low achievers. What was proved here was low achievers' inability to cope with the accelerated pace in which high achievers work when dealing with group work and pair work. This was, in fact, due to the huge difference in proficiency levels as well as their ability to respond to the teacher's instructions.

Regarding classroom participation, what was reflected through the study, however, is low achievers' reluctance to participate, which could be an indicator of their low level of motivation. It could also mean that they, generally, do not understand the lesson or the teacher's instructions, and consequently their inability to take benefits from the teaching/learning act. Light was shed on teacher's feedback as an indispensible constituent of classroom interaction. The majority of students involved claimed that the positive kind of interaction which usually exists between their teacher and the high achievers usually makes them withdraw from the learning scene as they cannot respond to the lesson the same way high achievers do. This reflects a negative attitude towards the learning act, and consequently an intensification in the feeling of inferiority and incapability. Again, the problem cannot, of course, be in the existence of high achievers in the classroom, the problem is with mixed ability classes where the difference in proficiency levels between students is huge.

Error correction was revealed to be problematic in this study in the sense that it might lead to error fossilization as well as students' misjudgment of their real proficiency level. The origin of the problem, as teachers claimed, was the huge number of errors low achievers usually commit, in addition to their inability to infer correct information from their teacher's feedback when she/he tries to lead them indirectly to the correct answer without inhibiting them with overcorrection.

The last point covered by the present research was communicative tasks and their effectiveness for limited proficiency level students. The research revealed that low achievers were, almost, taking no benefits from the communicative tasks or communicative activities. They claimed that communicative tasks were highly demanding for them and need a number of skills which they really ignore.

\section{Limitations of the study}

Despite the efforts exerted in it, and the important facts it revealed concerning the main problems low achievers face during communicative sessions, the present study involved some limitations. Starting with data collection methods, mainly students' questionnaire and interview and teachers' questionnaire and interview, in addition to classroom observations, although they disclosed many important facts about the investigated issue, they might be insufficient.

In addition to research instruments, the number of students and teachers involved in the study is small compared to the overall number of students in Tunisian secondary and preparatory school. Thus, the sample of this study may not be representative enough. Another factor that might influence the credibility of this research is the lack of seriousness from the part of some students in responding to the questions. In some answers they contradicted themselves. Other answers were not clear enough and I found myself obliged to guess what they wanted to say or the meaning of the written words, which 
may affect the credibility of the results obtained. In addition, some students were not serious enough about the questionnaire and interview, in some cases they left some questions without answers.

\section{Suggestions for further research}

The present research has revealed different difficulties faced by low achievers during communicative sessions. Therefore, it opens the gate for further research in order to support the findings of this paper and find other possible solutions to low achievers problems. For example, each of the principles followed in teaching English during communicative sessions, and which was proven to be problematic for low achievers can in itself be of topic or research for deeper understanding of the issue.

Funding: This research received no external funding

Acknowledgments: The author is

really thankful to the ESL teachers, the participant students, and the administrators in different regions in Tunisia who helped me achieve this work and make it possible

Conflicts of Interest: The author declares no conflict of interest.

\section{References}

[1] Ames, C. (1992). Classrooms: Goals, Structures, and student motivation. Journal of Educational Psychology, 84, $261-271$.

[2] BANDURA, A. (1993). Perceived self-efficacy in Cognitive development and functioning. Educational Psychologists, 28, 117-148.

[3] Bell, J., \& Burnaby, B. (1984). A Handbook for ESL Literacy. Toronto : OISE.

[4] Bremner, S. (2008). Some thoughts on teaching a mixed ability class. Scottish Languages Review, 18, 1-10.

[5] Campbell, C. \&Kryszewska, H. (1992). LEARNER-BASED TECHINGS. Oxford : Oxford University Press.

[6] Chaudron, C. (1988). Second Language Classrooms Research on teaching and Learning. Cambridge : Cambridge University Press.

[7] Covington, M. (1984). The motive for self-worth. In C, Ames, \& A, Ames, (Eds), Research on motivation in Education (Vol.1) (pp.77.113). New York : Academic Press.

[8] Cook, V. (1997). Second language learning and language teaching. Great Britain : JW Arrow smith Ltd, Bristol.

[9] Deci, E. L. \& Ryan, R. M. (1985). Intrinsic motivation and self determination in human behaviour. New York : Plenum.

[10] Denkci-Akkas, F., \& Coker, B. (2016). The use of communicative approach in 9th grade eflclasses. Eurasian Journal of Educational Research, 65, 71-90 10.14689/ejer.2016.65.05

[11] Dörnyei, Z. (1994). Understanding L2 Motivation : on with the challenge. Modern Language Journal, 78, 515-523.

[12] Dörnyei, Z. (1994). Motivation and motivating in the foreign language classroom. The Modern Language Journal ${ }_{2} 78,273-284$.

[13] Dörnyei, Z. \& Otto, I. (1998). Motivation in Action : A process model of L2 motivation. Working Papers in Applied Linguistics, Thames Valley University, London, Vol.4, 43-69.

[14] Dörnyei, Z. (1998). Motivation in second and foreign language learning. Language Teaching, 31, 117-135.

[15] Dörnyei, Z. (2003). Attitudes, Orientations, and Motivation in Language Learning : Advancers in theory, Research, and Applications. Language Learning. 53,51,3-32.

[16] Ellis, R. (1986). Understanding Language AcquisitionOxford : Oxford university Press.

[17] Ellis, R. (1990). INSTRUCTED SECOND LANGUAGE ACQUISITION. Learning in the classroom. Great Britain : T. J. Press Ltd, Padstow, Cornwall.

[18] Elizondo, B.L. (2013). The Mixed-Proficiency Language Class: Consequences for Students, Professors and the Institution. Letras 53 (2013), ISSN 1409-424X; EISSN 2215-4094

[19] Gardner, R. C. (1985). Social psychology and language learning : The role of Attitude and Motivation. London : Edward Arnold.

[20] Gardner, R. C. \& Lambert, W. (1972). Attitudes and Motivation in Second Language Learning. Rowley, Mass : Newburg House.

[21] Hermassi, T. (2003). Motivation, Classroom participation and achievement in The Tunisian E.F.L Context. Unpublished Doctoral thesis. I.S.L.T. Tunis.

[22] Johnson, K (2001) An introduction to foreign language learning and teaching: Pearson Education Language Acquisition. Oxford : Oxford University Press.

[23] Kumaravadivelu, B. (1994). The PostmethodCondition : Emerging Strategies for Second / Foreign Language Teaching. TESOL Quarterly 28(1), 27-48

[24] Kumaravadivelu, B. (2003a). Beyond methods: Macrostrategies for language teaching. New Haven, CT: Yale University Press.

[25] Kumaravadivelu, K. (2008). Understanding Language Teaching. From Method to Post-Method. New Jersey. Lawrence Erlbaum Associates, Inc., Publishers

[26] Lilttlewoad, W. (1981). Communicative Language Teaching : An introduction. Cambridge : Cambridge University Press.

[27] Locke, E. A \&Lathman, G. P (1994). Goal setting theory. In H. F O'Neil, Jr. \& M. Drillings (eds.), Motivation : theory and research, 13-19.

[28] Noels, K. A., Pelletier, L. G., Clément, R., \& Vallerand, R. J. (2000). Why Are You Learning a second Language ? Motivational Orientation and Self-Determination Theory. Language Learning, 50,(1), 57-85.

[29] Numan, D. (1989). Designing Tasks for the communicative classroom. Cambridge University Press.

[30] Richards, J. C. (2006). Communicative language teaching today. The USA: Cambridge UniversityPress. 
[31] Syathroh, I.L; Musthafa, B. ;Purnawarman, P. (2019). Investigating Indonesian Teachers' Strategies of Teaching English in mixed Ability Classes. ELTIN Journal, 7(II), 60-74.

[32] Pintrich, P., \& Schunk, D. (1996). Motivation in education : Theory, research, and applications. Englwood Cliffs, NJ : Merrill.

[33] Swan, M. (1985). A critical look at the communicative Approach (2). ELT Journal. 39(2.

[34] Troike, M. S. (2006). Introducing Second Language Acquisition. Cambridge : Cambridge University Press.

[35] Waugh, W. (2004). Motivation and its role in Language Acquisition.

[36] Zhisheng, W. (2008). IS NOTICING VITAL FOR L2 LEARNING? - A CRITICAL REVIEW OF SCHMIDT'S "NOTICING HYPOTHESIS". Celea Journal,31(3) 3-8.. 